\title{
Reliability of Towel Test for Elbow Flexion Assessment in Brachial Plexus Birth Palsy
}

\author{
J. Terrence Jose Jerome ${ }^{1, \odot}$ \\ S. Vanathi
}

G. Ramesh Prabu ${ }^{3}$

K. Thirumagal ${ }^{4}$

\begin{abstract}
Address for correspondence J. Terrence Jose Jerome, MBBS, FRCS, DNB, MNAMS, FNB (Hand \& Microsurgery), FICS, PGDMLE, Department of Orthopedics, Hand and Reconstructive Microsurgery, Olympia Hospital and Research Centre, 47, 47A Puthur High Road, Puthur, Trichy, Tamil Nadu 620017, India (e-mail: terrencejose@ gmail.com).
\end{abstract}

\begin{abstract}
Keywords

- brachial plexus birth palsy

-6 months

- 9 months

- towel test

- false negativity

- handedness

Background and Objectives The towel test is a reliable and straightforward technique to find elbow flexion in brachial plexus birth palsy. This study evaluates the role and reliability of towel test in children at 6 and 9 months of age.

Materials and Methods We conducted the towel test in 30 consecutive children at 6 and 9 months of their ages between 2015 and 2020. We recorded the results along with the side involved in these children and the mother's handedness. Based on the results of towel tests, we did a statistical correlation.

Results Sixteen of the 30 children were boys. Twelve of the 30 children had left-side involvement. Four mothers were left handed. Four $(13 \%)$ infants ( male $=3$; female $=1$ ) had false-negative towel test at 6 and 9 months. There is a significant correlation between the left-hand mother's and infant who had false-negative towel test $(p<0.01)$ Conclusion The towel test is reliable and straightforward to assess the elbow flexion at 6 and 9 months. It can be falsely negative in 13\% of children because of handedness. Mother's handedness is crucial and should be recorded during the children assessment. Alternate tests will further evaluate the elbow flexion in such false-negative towel-tested brachial plexus birth palsy children.
\end{abstract}

\section{Introduction}

Simple clinical examination, standard tests, and assessment tools help decision-making for brachial plexus birth palsy. ${ }^{1,2}$ The simple test described by Bertelli and Ghizzoni is a towel test and done between 6 and 9 months. ${ }^{1,2}$ Normally, when a child's face is covered with a towel, he/she tries to remove the towel. The test will give a clear assessment of shoulder function and elbow flexion. ${ }^{3,4}$ In brachial plexus birth palsy, the child tries to remove the towel by the normal upper limb, whereas the affected side has no or less movements. There have been instances where the child strives to remove the towel by the affected upper limb. This intrigues brachial plexus surgeons to find the cause or the reason behind this. It is well known that $10 \%$ of children born are left-handed, and the children's preference to adopt to left hand can develop at 6 months of age., ${ }^{5,6}$ There is no study published online August 24, 2021
DOI https://doi.org/ $10.1055 / \mathrm{s}-0041-1732787$ ISSN 0973-0508 (c) 2021. Neurotrauma Society of India.

This is an open access article published by Thieme under the terms of the Creative Commons Attribution-NonDerivative-NonCommercial-License, permitting copying and reproduction so long as the original work is given appropriate credit. Contents may not be used for commercial purposes, or adapted, remixed, transformed or built upon. (https://creativecommons.org/licenses/by-nc-nd/4.0/). Thieme Medical and Scientific Publishers Pvt. Ltd. A-12, 2nd Floor, Sector 2, Noida-201301 UP, India 
to assess the effect of handedness and the influence on the towel test.

The study's purpose was to evaluate the role and reliability of towel test in brachial plexus birth palsy children at 6 and 9 months of age and correlate with the child handedness.

\section{Materials and Methods}

\section{Patients, Setting, and Ethics}

This retrospective study was approved by the institutional ethical committee review board between 2015 and 2020. We evaluated 30 consecutive infants ( 16 boys and 14 girls) with brachial plexus birth palsy for elbow flexion recovery, using a towel's test, done at 6 and 9 months of age. We also noted the details about brain pathology, perinatal brain insults, bacterial meningitis, and birth asphyxia from the infant's birth record and documented additional information from the mother or father. The side involved in these infants and the mother's handedness was recorded. The infants were assessed in the supine position, and the pictures and videos were taken with parents' consent.

\section{Towel's Test}

We covered the child's face with a towel. The child immediately tries to remove the towel by using the normal upper limb. This is a positive test. The test is considered false-negative when the child tries and uses the affected upper limb instead of the normal limb to move the towel away. All towel tests were repeated at least three times in the outpatient clinic with an interval of 10 minutes. The test is considered positive or false negative when the child does more than one out of the three tests.

\section{Statistics}

We compared the clinical results of the test done at 6 and 9 months with the Chi-squared test and other parameters with Mann-Whitney $U$-test. A value of $p<0.05$ was accepted as statistically significant.

\section{Results}

Sixteen of the 30 children were boys. Twelve of the 30 children had left-side involvement. Four mothers were left-handed. Twenty-six children (87\%) had a positive towel test where they moved the normal upper limb to remove the towel away. Four left-handed children $(13 \%$; male $=3$; female $=1$ ) whose mothers were left-handed had a false-negative towel test at 6 and 9 months. There is a significant correlation between the left-hand mother's and the left-handed infant's towel test $(p<0.01$; - Table 1$)$. None of the infants had brain pathology, perinatal brain insults, bacterial meningitis, or birth asphyxia.

The pediatrician, neurologist, and the author examined the normal upper limb in these four infants and found normal. Besides they played well with toys, rattles and bells, and cookies with the normal upper limb. But during the towel test, these four infants used the affected limb to remove the towel at 6 and 9 months of their ages (-Figs. 1 and 2 ). Also, they rotated the face and the body toward the affected side ( $\mathbf{V}$ Videos $\mathbf{1}$ and $\mathbf{2}$, available in the online version only).

\section{Video 1}

The absence of towel removal by the normal hand at 6 months. Weak left upper limb attempts to remove the towel. Online content including video sequences viewable at:https://www.thieme-connect.com/products/ejournals/ html/10.1055/s-0041-1732787

\section{Video 2}

At 9 months, the same child tries to remove the towel with the improving left upper limb and ends us shifting, rolling the entire body to the right side. The normal rightside upper limb did not try and remove the towel. Online content including video sequences viewable at: https:// www.thieme-connect.com/products/ejournals/html/10.1 055/s-0041-1732787

\section{Discussion}

The modified Mallet Score, Toronto score test, and active movement score (AMS) are tests used to assess the motor recovery pattern in brachial plexus birth palsy. ${ }^{1,7,8}$ Yet, there is no comprehensive and comparative tests to determine nerve recovery. ${ }^{9,10}$ Towel test is a simple test done in the outpatient clinic and proved a practical test in biceps flexion evaluation. The most important single prognostic sign is the recovery

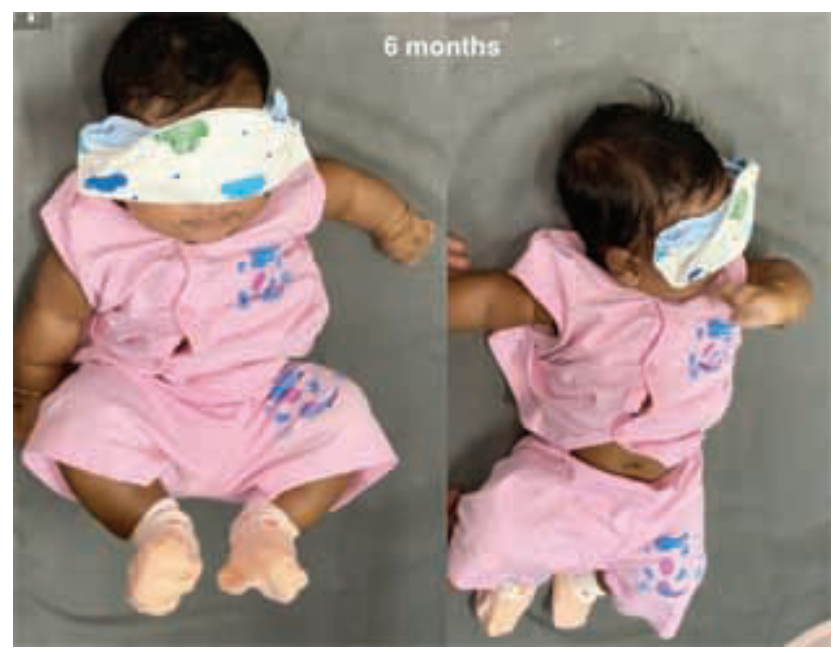

Fig. 1 Left-side brachial plexus birth palsy involving $\mathrm{C} 5$, 6, and 7 nerve roots with weak hand function. There is no Horner's syndrome. Towel test at 6 months shows no movement at the normal right upper limb but weak and attempted shoulder abduction in the left upper limb. The mother was left-handed. 
Table 1 Comparison of towel test between 6 and 9 months

\begin{tabular}{|c|c|c|c|c|c|}
\hline Patient no & Gender & Side & $\begin{array}{l}\text { Mother } \\
\text { handedness }\end{array}$ & $\begin{array}{l}\text { Towel test at } 6 \\
\text { months }\end{array}$ & Towel test at 9 months \\
\hline 1 & Male & Left & Right & Positive & Positive \\
\hline 2 & Female & Right & Right & Positive & Positive \\
\hline 3 & Male & Right & Right & Positive & Positive \\
\hline 4 & Female & Right & Right & Positive & Positive \\
\hline 5 & Female & Right & Right & Positive & Positive \\
\hline 6 & Male & Left & Left & Negative & Negative \\
\hline 7 & Male & Left & Left & Negative & Negative \\
\hline 8 & Male & Right & Right & Positive & Positive \\
\hline 9 & Male & Right & Right & Positive & Positive \\
\hline 10 & Female & Right & Right & Positive & Positive \\
\hline 11 & Male & Left & Right & Positive & Positive \\
\hline 12 & Female & Right & Right & Positive & Positive \\
\hline 13 & Female & Right & Right & Positive & Positive \\
\hline 14 & Female & Right & Right & Positive & Positive \\
\hline 15 & Male & Right & Right & Positive & Positive \\
\hline 16 & Male & Left & Right & Positive & Positive \\
\hline 17 & Male & Right & Right & Positive & Positive \\
\hline 18 & Male & Left & Right & Positive & Positive \\
\hline 19 & Female & Left & Left & Negative & Negative \\
\hline 20 & Female & Left & Right & Positive & Positive \\
\hline 21 & Female & Right & Right & Positive & Positive \\
\hline 22 & Male & Right & Right & Positive & Positive \\
\hline 23 & Female & Left & Right & Positive & Positive \\
\hline 24 & Male & Right & Right & Positive & Positive \\
\hline 25 & Male & Right & Right & Positive & Positive \\
\hline 26 & Female & Right & Right & Positive & Positive \\
\hline 27 & Male & Right & Right & Positive & Positive \\
\hline 28 & Female & Left & Right & Positive & Positive \\
\hline 29 & Female & Left & Right & Positive & Positive \\
\hline 30 & Male & Left & Left & Negative & Negative \\
\hline
\end{tabular}

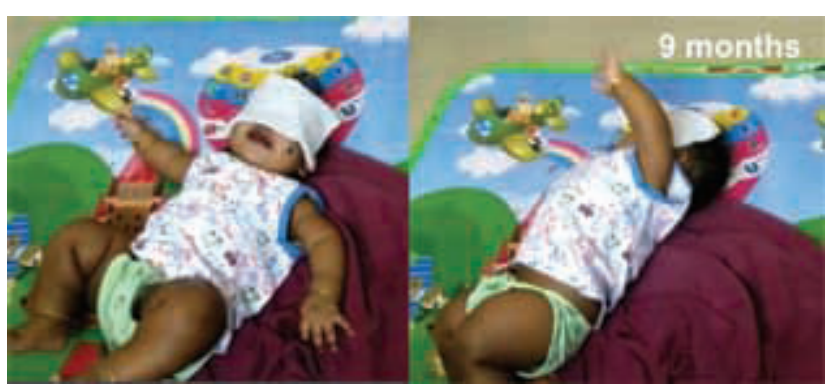

Fig. 2 At 9 months, the affected side left upper limb and the body shifts to the right side to remove the towel. There is no movement in the normal right upper limb.

of elbow flexion in brachial plexus birth palsy. ${ }^{1-4,7,9,10}$ The absence of elbow flexion at 3 to 9 months is an important criterion to operate. Besides clinical evaluation, electromyography can predict the flexion recovery but it can overestimate the recovery. ${ }^{11}$
Bertelli and Ghizzoni observed that the towel test's goal is to induce motion and provoke arm movements. The ideal age to perform this test is 6 to 9 months, where children's voluntary movements replace the primitive reflexes. ${ }^{1}$

Children of 6 months have $80 \%$ and children of 9 months of age have $100 \%$ ability to remove the towel from the face by their elbow flexion assisted with shoulder and hand movements. ${ }^{12}$ Our study documented that the results at 6 and 9 months are the same, and the children had $100 \%$ ability to remove the towel at 6 months by elbow flexion.

Our study documented that 26 infants removed the towel quickly using the normal hand, and the affected side had weak or absent biceps contraction at 6 and 9 months of their ages. Four infants (13\%) did not remove the towel using their normal hand despite multiple attempts with otherwise normal neuromotor functions in the normal upper limb. Instead, they made a full effort to remove the towel by the affected limb. To achieve this despite weakness and difficulty, these 
Table 2 Impact of the elbow flexion on the outcome

\begin{tabular}{|l|l|l|l|l|l|}
\hline SI. no. & Elbow flexion & Towel test & Surgery & $\begin{array}{l}\text { Overall limb } \\
\text { outcome at 3 years }\end{array}$ & Secondary surgery \\
\hline 6 months & No & Positive & $\begin{array}{l}\text { extraplexal nerve transfer/nerve repair/ } \\
\text { nerve grafting surgery }\end{array}$ & Good & $\begin{array}{l}\text { Low secondary } \\
\text { surgery (31\%) }\end{array}$ \\
\hline 6 months & Yes & Negative & Conservative & Good & Not needed \\
\hline 9 months & No & Positive & Conservative & Good & Not needed \\
\hline 9 months & Yes & Negative & $\begin{array}{l}\text { extraplexal nerve transfer/nerve repair/ } \\
\text { nerve grafting surgery }\end{array}$ & Good & $\begin{array}{l}\text { Low secondary } \\
\text { surgery (18\%) }\end{array}$ \\
\hline
\end{tabular}

four infants moved their entire body (shoulder, arm, forearm, and hand) toward the opposite side in an attempt to remove the towel. These observations confirmed the false negativity of the towel test.

\section{Impact of False-Negative Towel's Test and Elbow Flexion on the Outcome}

The infant's elbow flexion recovery decides the course of the treatment (Table 2).$^{13}$ False-negative test alarms the clinicians to have a high index of suspicion about handedness. If the child tries and lifts the involved limb instead of the normal limb, then the towel test becomes false-negative. In addition to elbow flexion, wrist and hand movements should also be taken into considerations before surgery.

\section{Cortical Reorganization versus Peripheral Nerve Changes/Injury}

It is evident for a reason that elbow flexion recovery occurs $1 \mathrm{~mm} /$ day following a peripheral nerve injury like brachial plexus palsy. The movements seen in the affected limb are due to the reinnervation of the elbow flexor muscles.

Cortical reorganization results from damage to the central nervous system (surgery, stroke, etc.) or spinal cord injury, causing motor deficit and remain for a long duration. Functional benefits from rehabilitation evince the mature human brain potential for rewiring and remodeling which has clinical and neurobiological phenomenon intercorrelated. Neuroplasticity is the main reason for cortical reorganization. ${ }^{14}$

Studies involving no surgical intervention have focused on sensorimotor network (SMN) and its activity response to the injury. Many authors have noted a decreased activation in the SMN, and cortical maps of sensorimotor areas associated with hand and arm function contralaterally had a weaker correlation than the ipsilateral side. ${ }^{14,15}$ Few authors highlighted that changes in resting-state network (RSN) are a dynamic process, and patients included in studies involving resting-state functional magnetic resonance imaging (fMRI) need to be followed-up. Thus, these studies need to be of long-term duration in nature. ${ }^{16}$

The current literature has enough evidence to prove, based on fMRI studies that cortical reorganization occurs in brachial plexus injury. It is interesting to note that RSN is usually linked to cognitive and higher mental functions altered following a functionally distant injury and recovery. ${ }^{16}$

Resting fMRI is an essential tool in understanding cortical reorganization in central nervous system diseases and peripheral nerve injuries. Whether the changes result from injury and recovery or whether they play a role in the recovery of functions is not clear. This may be answered by the conduction of longitudinal studies focusing on resting fMRI, performed over several years, right from the time of injury to years following partial or complete recovery. ${ }^{17,18}$

There is an exciting link between brain pathology and handedness with genetic components passed by left-hand mothers. ${ }^{19}$ In addition to genetic effects, reduced cognitive performance in left-handers could result from brain pathology, perinatal brain insults, bacterial meningitis, females, older mothers, and birth asphyxia. ${ }^{20-22}$

Our study noted that four mothers with left-handedness had their infants' left upper limb affected by brachial plexus birth palsy where the towel test was a false negative. These four infants used the left upper limb to remove the towel instead of the normal right upper limb. We documented that left-hand mothers have significant influence over the growing baby's handedness, and the test can be false negative in their infants $(p<0.01)$. None of these infants had perinatal insults, bacterial meningitis, or brain pathology.

The left-handed population accounts for 10 to $12 \%$ in the world's total population and may vary between the countries. ${ }^{5}$ Majority of the children develop a clear hand preference at 6 months of age, ${ }^{23}$ and further development rate is variable. ${ }^{24}$ Our study noted $13 \%$ of left-handed children at 6 months of age and confirmed the same at 9 months of age by the false-negative towel test. Girls are less likely to be left-handed than boys. ${ }^{25}$ In our study, 14 of the 30 infants were girls, and we had no significant impact on the towel test.

The towel test is reliable and straightforward to assess the elbow flexion in an infant at 6- and 9-month of age. This test has $13 \%$ false negativity which may be attributed to the handedness of the infant. Surgeons should be aware of and have a high index of suspicion while performing the towel test. Alternate assessment tools can be provoked to grade the movements. This study reported an interesting follow-up of towel test at 6 and 9 months in children with false negative and left handedness. The towel test is a simple test to establish early hand preference in these infants as early as 6 months of age.

Resting-state fMRI may be beneficial in the future in understanding the cortical reorganization in brachial plexus birth palsy and guide us to a time-based intervention to achieve favorable outcome and prognosis. Multiple resting-state MRI may be advantageous to look for the nerve recovery/progression after injury and nerve repair. Though rest-fMRI timing is debatable, a consensus on this will ensure more information about brachial plexus birth palsy in the future. 


\section{Limitations}

Our study's limitation is the small sample size, retrospective observational design, and no electromyography study. The towel test aids EMG studies and demonstrates that $>50 \%$ of the normal contralateral biceps amplitude is needed for complete elbow flexion. EMG helps in demonstrating muscle potentials and complete denervation. Also, it indicates recovery when there is a repeated increase in amplitude. Sometimes, it can overestimate the biceps recovery. The cocontraction of the biceps and triceps in brachial plexus birth palsy limits the use of EMG. It can show coactivation of biceps and triceps but no cocontractions.

\section{Conclusion}

Surgeons should be aware that the towel test may have 13\% false negativity. This can be appreciated during the elbow flexion recovery assessment in brachial plexus birth palsy where the affected limb moves to take the towel away instead of the normal limb. One should always include the mother's handedness which may have the impact of the infant's handedness. Towel test may predict the handedness in false-negative cases. The towel test determines the elbow flexion recovery in brachial plexus birth palsy. It can have $13 \%$ false negativity because of the handedness of the infants. Towel test is a reliable indicator for early hand preference in infants as early as at 6 months. One should always include the mother's handedness during the evaluation of the brachial plexus birth palsy assessment. EMG may help in these false negativity cases, but it can overestimate the biceps recovery. Additional tests and scores will help in these circumstances. Resting fMRI is the future diagnostic tool in understanding cortical reorganization and plays a crucial role in determining these injuries' intervention time and outcome.

\section{Ethical Approval and Consent to Participate}

Ethical approval and consent to participate for this study was obtained from Ethical Committee Board of Olympia Hospital and Research Centre, approval no.: 15/2020.

\section{Consent for Publications}

Written and verbal consent were obtained from the parents for publication.

\section{Funding \\ None.}

\section{Authors' Contributions}

All authors equally contributed to writing, planning, reviewing, correcting, collecting data, and preparing final draft.

\section{Conflict of Interest \\ None declared.}

\section{References}

1 Bertelli JA, Ghizoni MF. The towel test: a useful technique for the clinical and electromyographic evaluation of obstetric brachial plexus palsy. J Hand Surg [Br] 2004;29(2):155-158
2 Pondaag W, Malessy MJ, van Dijk JG, Thomeer RT. Natural history of obstetric brachial plexus palsy: a systematic review. Dev Med Child Neurol 2004;46(2):138-144

3 Gilbert A. Long-term evaluation of brachial plexus surgery in obstetrical palsy. Hand Clin 1995;11(4):583-594, discussion 594-595

4 Clarke HM, Curtis CG. An approach to obstetrical brachial plexus injuries. Hand Clin 1995;11(4):563-580, discussion 580-581

5 Aggleton JP, Kentridge RW, Good JMM. Handedness and musical ability: a study of professional orchestral players, composers, and choir members. Psychol Music 1994;22:148-156

6 Johnston DW, Nicholls ME, Shah M, Shields MA. Nature's experiment? Handedness and early childhood development. Demography 2009;46(2):281-301

7 Curtis C, Stephens D, Clarke HM, Andrews D. The active movement scale: an evaluative tool for infants with obstetrical brachial plexus palsy. J Hand Surg Am 2002;27(3):470-478

8 Greenwald AG, Schute PC, Shiveley JL. Brachial plexus birth palsy: a 10-year report on the incidence and prognosis. J Pediatr Orthop 1984;4(6):689-692

9 Greenhill DA, Lukavsky R, Tomlinson-Hansen S, Kozin SH, Zlotolow DA. Relationships between 3 classification systems in brachial plexus birth palsy. J Pediatr Orthop 2017;37(6):374-380

10 Borschel GH, Clarke HM. Obstetrical brachial plexus palsy. Plast Reconstr Surg 2009;124(1(suppl) :144e-155e

11 Van Dijk JG, Pondaag W, Buitenhuis SM, Van Zwet EW, Malessy MJ. Needle electromyography at 1 month predicts paralysis of elbow flexion at 3 months in obstetric brachial plexus lesions. Dev Med Child Neurol 2012;54(8):753-758

12 Lefèvre AB, Diament AJ, Neurologia Infantil. São Paulo, Brazil: Sarvier; 1980 125-126

13 Fisher DM, Borschel GH, Curtis CG, Clarke HM. Evaluation of elbow flexion as a predictor of outcome in obstetrical brachial plexus palsy. Plast Reconstr Surg 2007;120(6):1585-1590

14 Ding Y, Kastin AJ, Pan W. Neural plasticity after spinal cord injury. Curr Pharm Des 2005;11(11):1441-1450

15 Moxon KA, Oliviero A, Aguilar J, Foffani G. Cortical reorganization after spinal cord injury: always for good? Neuroscience 2014;283:78-94

16 Thaploo D, Bhat DI, Kulkarni MV, Devi BI. Brachial plexus injury and resting-state fMRI: need for consensus. Neurol India 2019;67(3):679-683

17 Grinsell D, Keating CP. Peripheral nerve reconstruction after injury: a review of clinical and experimental therapies. BioMed Res Int 2014;2014:698256

18 Yoshikawa T, Hayashi N, Tajiri Y, Satake Y, Ohtomo $\mathrm{K}$. Brain reorganization in patients with brachial plexus injury: a longitudinal functional MRI study. ScientificWorldJournal 2012;2012:501751

19 Pipe ME. Pathological left-handedness: is it familial? Neuropsychologia 1987;25(3):571-577

20 Bakan P, Dibb G, Reed P. Handedness and birth stress. Neuropsychologia 1973;11(3):363-366

21 Satz P, Orsini DL, Saslow E, Henry R. The pathological left-handedness syndrome. Brain Cogn 1985;4(1):27-46

22 Snyder PJ, Harris LJ. Handedness, sex, and familial sinistrality effects on spatial tasks. Cortex 1993;29(1):115-134

23 Johnston DW, Nicholls MER, Shah M, Shields MA. Nature's experiment? Handedness and early childhood development. Demography 2009;46(2):281-301

24 Michel GF, Tyler AN, Ferre C, Sheu CF. The manifestation of infant hand-use preferences when reaching for objects during the seven-to thirteen-month age period. Dev Psychobiol 2006;48(6):436-443

25 Miller JW, Jayadev S, Dodrill CB, Ojemann GA. Gender differences in handedness and speech lateralization related to early neurologic insults. Neurology 2005;65(12):1974-1975 